\title{
In-vitro Efficacy of different Bioagents against Dry Root Rot Disease of Groundnut
}

\author{
Badana Manoj Kumar ${ }^{1 *}$ and D. S. Kelaiya ${ }^{2}$ \\ ${ }^{1}$ Department of Plant Pathology, ${ }^{2}$ Main Oilseed Research Station, Junagadh Agricultural \\ University, Junagadh -362 001, Gujarat, India \\ *Corresponding author
}

Keywords

In-vitro, mycelial growth inhibition, antagonist and colony diameter

Article Info

Accepted: 12 May 2021 Available Online: 10 June 2021

\section{Introduction}

Groundnut (Arachis hypogaea L.) is a cultivated annually belonging to the plant family Leguminosae and sub family Papillionaceae. It is an important oilseed crop of the semi arid tropics (SAT). A variety of stresses affect groundnut production from planting to storage. Among these diseases are the major causes of losses in production. The majority of diseases are caused by fungi and several of them caused reduction in yield (Mayee, 1995). Among these, soil borne fungal pathogens causing serious losses and have prime importance (Mathur and Cunfer, 1993). Generally, these pathogens infect underground parts of the plant and reduce yield (Wisniewska and Chelkowski, 1999). Due to this disease production and quality of groundnut is hampered.

The groundnut \& other legumes in India often suffer from various type of root rot \& wilt. Among these the dry root rot caused by Macrophomina phaseolina (Tassi) Goid has been noticed to cause $33.33 \%$ seed rotting 
and $23.80 \%$ post emergence mortality (Gupta and Kolte, 1982). Macrophomina phaseolina is a soil borne fungus causing the root rot disease on groundnut and is one of the cosmopolitan fungi. It has also been observed in Saurashtra region of gujarat during summer or kharif.

Due to several side effect of chemicals used in plant disease management has diverted plant pathologists or mankind to find out the other alternative methods for plant disease control with antagonistic microorganism. An experiment was undertaken to determine the antagonistic effect of different biocontrol agent against $M$. phaseolina fungus causes of root rot disease of groundnut.

\section{Materials and Methods}

\section{Evaluation of biocontrol agents in vitro}

Effect of fungal biocontrol agents on the growth of $M$. phaseolina

The antagonistic actions of five different Trichoderma Spp. were tested against $M$. phaseolina by using dual culture technique (Morton and Stroube, 1955) in CRD with three repetitions.

Twenty milliliters of sterilized melted PDA were poured aseptically in each $90 \mathrm{~mm}$ Petri plates and were allowed to solidify. Mycelial disc of four millimeter diameter of each antagonist and test fungus was cut with the help of sterilized cork borer from the edges of actively growing culture and were placed by keeping $1 \mathrm{~cm}$ distance from distal ends of PDA containing Petri plates. The plates were then incubated at $28 \pm 2^{\circ} \mathrm{C}$ for five days.

After incubation the growth of antagonist and test fungus was measured by linear measurement. Per cent growth inhibition of test fungus by antagonist was calculated.

\section{Effect of bacterial biocontrol agents on the growth of M. phaseolina}

The antagonistic action of Pseudomonas fluorescens and Bacillus Spp. were tested against $M$. phaseolina by using dual culture technique. Twenty milliliters of NA were poured aseptically in each Petri plates and allowed to solidify. Mycelial disc of four $\mathrm{mm}$ diameter of test fungus was placed at both distal end of Petri dish by keeping $1 \mathrm{~cm}$ distance from the edges of the Petri dish and bacterial antagonist inoculated at the center with inoculating wire loop by streaking method. Each treatment was repeated thrice and arranged in CRD. The plates were then incubated at $28 \pm 2 \mathrm{oC}$ for five days. After incubation the growth of antagonist and test fungus was measured by linear measurement.

Per cent growth inhibition of test fungus by antagonist was calculated by using formula given by Vincent (1947).

$$
\begin{aligned}
& \text { Per cent growth inhibition (PGI) } \\
& \mathrm{C}-\mathrm{T} \\
& =----\times 100 \\
& \mathrm{C}
\end{aligned}
$$

Where,

$\mathrm{C}=$ Average diameter of mycelial colony in control treatment $(\mathrm{mm}) \mathrm{T}=$ Average diameter of mycelial colony in treated plate $(\mathrm{mm})$

\section{Sclerotial formation}

Sclerotial formation was counted in fungal and bacterial culture suspensions under the microscope at low power (10X).

\section{Results and Discussion}

The hazardous effect of chemicals used in the plants disease management has diverted plant pathologists to find out the alternative 
methods having little or no adverse effect on environment. There is a possibility of developing biological control agent for management of plant disease under field condition. The commercial formulation of bio agents are already available in the market. An experiment was conducted to determine the antagonistic action of five fungal bio agents viz, Trichoderma harzianum, T. viride, $T$. virens, T. hamatum, and T. koningii and two bacterial bioagents Pseudomonas fluorescens and Bacillus subtilis against the test fungus by dual culture technique. Based on observation on radial growth of antagonist and test fungus, per cent inhibition was calculated. The results presented in table 3, plate-1 and depicted in Fig.1. makes it clear that, all the antagonists are tested against $M$. phaseolina were effective in checking the growth of the pathogen. Out of seven antagonists tested, maximum inhibition over control was recorded in Trichoderma viride (75.42 \%) which are statically at par with $T$. harzianum (73.61 \%). While Pseudomonas fluorescens $(68.17 \%)$ was found next best followed by $T$. virens $(64.64 \%)$ and T.hamatum (63.66\%) were moderately effective to inhibit fungal growth. Least inhibition was recorded in $T$. koningii $(54.38 \%)$ and B. subtilis $(47.28 \%)$.

Moderate sclerotial formation were observed in T. koningii and B. subtilis whereas sclerotial formation was absent in rest of the treatments. It is evident from these studies that among all the antagonists evaluated by dual culture method, $T$. viride and $T$. harzianum consistently showed strong antagonistic property against $M$. phaseolina compared to the other antagonists tested hence considered as potential antagonists.

Table.1 List of different bio-control agents tested against $M$. phaseolina in vitro

\begin{tabular}{|c|c|}
\hline Sr. No. & Name of the antagonist \\
\hline 1 & Trichoderma harzianum \\
\hline 2 & Trichoderma virens \\
\hline 3 & Trichoderma viride \\
\hline 4 & Trichoderma hamatum \\
\hline 5 & Trichoderma koningi \\
\hline 6 & Pseudomonas fluorescens \\
\hline 7 & Bacillus subtilis \\
\hline 8 & Control \\
\hline
\end{tabular}

Table.2 Sclerotial formation

\begin{tabular}{|c|c|c|}
\hline $\begin{array}{c}\text { No. of sclerotia per } \\
\text { microscopic field }\end{array}$ & Grade & Sign \\
\hline 0 & Absent & - \\
\hline $1-4$ & Scanty & + \\
\hline $\mathbf{5 - 8}$ & Moderate & ++ \\
\hline $\mathbf{9 - 1 5}$ & Good & +++ \\
\hline$>15$ & Abundant & ++++ \\
\hline
\end{tabular}


Table.3 Effect of different bio-agents against $M$. phaseolina in vitro condition

\begin{tabular}{|c|c|c|c|}
\hline Sr. No & Bio control agents & $\begin{array}{l}\text { Percent inhibition } \\
\text { over control* }(\%)\end{array}$ & $\begin{array}{l}\text { Sclerotial } \\
\text { formation }\end{array}$ \\
\hline 1. & Trichoderma harzianum & $\begin{array}{c}59.09 \\
(73.61)\end{array}$ & - \\
\hline 2. & Trichoderma virens & $\begin{array}{c}53.33 \\
(64.34)\end{array}$ & - \\
\hline 3. & Trichoderma viride & $\begin{array}{c}60.23 \\
(75.42)\end{array}$ & - \\
\hline 4. & Trichoderma hamatum & $\begin{array}{c}52.93 \\
(63.66)\end{array}$ & - \\
\hline 5. & Trichoderma koningi & $\begin{array}{c}47.51 \\
(54.38)\end{array}$ & ++ \\
\hline 6. & Pseudomonas fluorescens & $\begin{array}{c}55.65 \\
(68.17)\end{array}$ & - \\
\hline \multirow[t]{4}{*}{7.} & Bacillus subtilis & $\begin{array}{c}43.44 \\
(47.28)\end{array}$ & + \\
\hline & S.Em. \pm & 0.71 & \\
\hline & C. D. at $5 \%$ & 2.06 & \\
\hline & C.V. \% & 2.28 & \\
\hline \multicolumn{4}{|c|}{$\begin{array}{l}\text { Sclerotial formation: } \\
+++=\text { Abundant; }+++=\text { good; }++=\text { moderate; }+=\text { scanty; }-=\text { no sclerotial formation. } \\
\text { *Average of three replications } \\
\text { Values in parentheses are re-transformed values while outside were transformed with arcsine transformation before analysis }\end{array}$} \\
\hline
\end{tabular}

Plate.1 Effect of different bio-agents against $M$. phaseolina in vitro

1. Trichoderma harzianum

2. Trichoderma hamatum

3. Trichoderma viride

4. Trichoderma virens
5. Trichoderma koningii

6. Pseudomonas fluorescens

7. Bacillus subtilis

8. Control

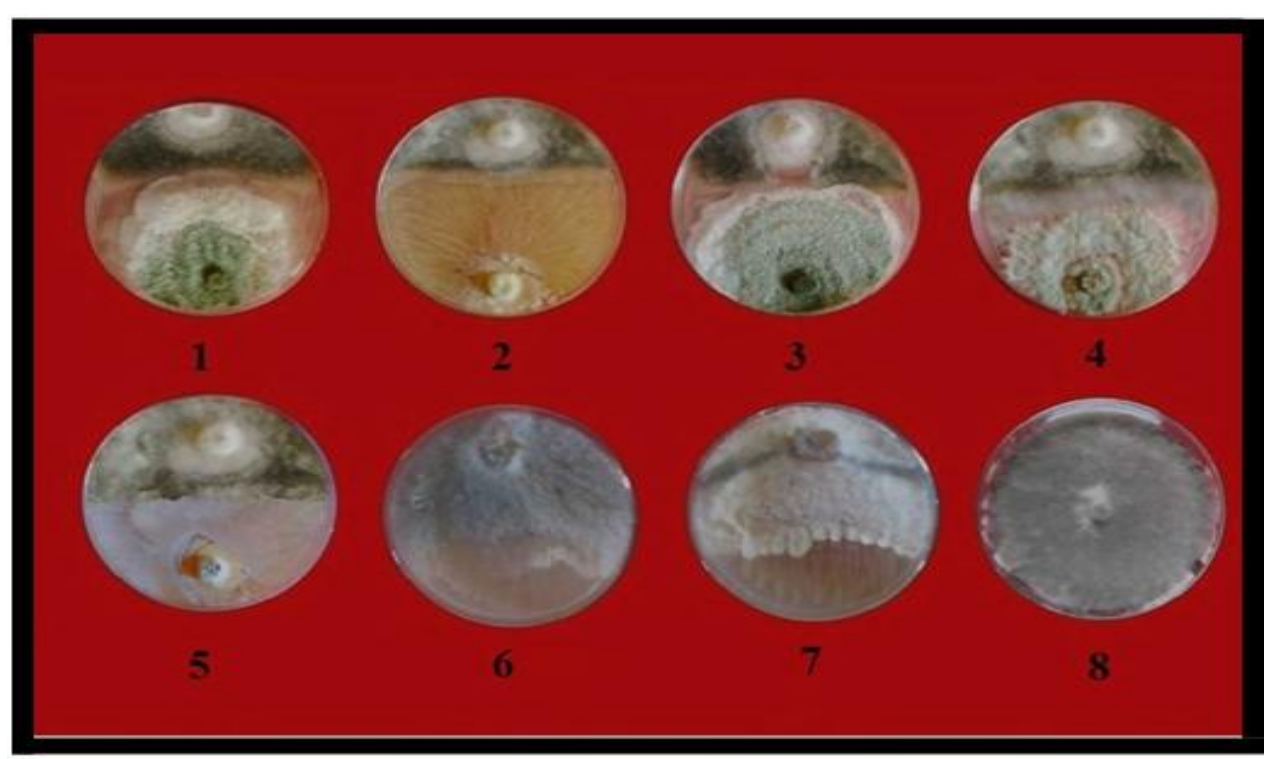


Fig.1 Effect of different biocontrol agents against M. phaseolina in vitro

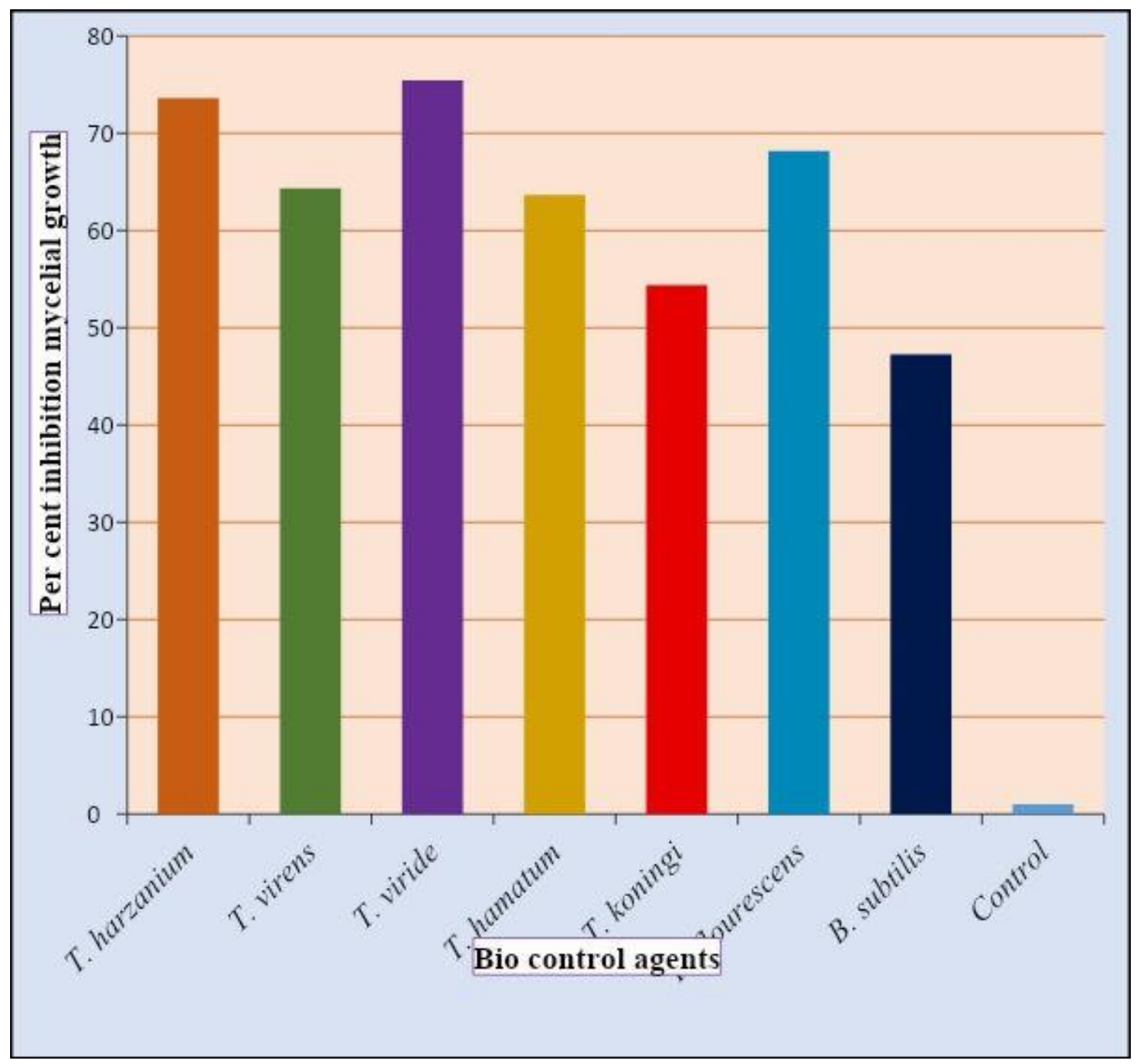

This results are congruent with Rajeshwari et al., 1998; Ahmad and Shrivastava, 2000; Indra and Tribhuvanmala, 2002; Malathi and Sabitha, 2004; Suriachandra selvan et al., 2004; Rani et al., 2009; Chaudhary et al., 2010; Sreedevi et al., 2015; Dhingani and Kelaiya, 2015; Kumar et al., 2015; Meena and Pandey, 2015 and Gojiya et al., 2016 who reported $T$. harzianum and $T$. viride as a strong antagonist against $M$. phaseolina in dual culture technique.

Pseudomonas fluorescens was found effective against M. phaseolina (dry root rot of chickpea) under dual culture technique have been earlier reported by Ahmad and Shrivastava (2000). Kumar et al., (2007), Lokesha and Benagi (2007), Manjutha et al., (2013) and Mallaiah and Krishna Rao (2016) were also reported $P$. fluorescence was found effective in inhibiting the growth of $M$. phaseolina.

\section{References}

Ahmad, S., and Srivastava, M. 2000. Biological control of dry root rot of chickpea with plant products and antagonistic microorganism. Ann. Agric. Res. 21(3): 450-451. 
Choudhary, S., Pareek, S., and Saxena, J. 2010. Efficacy of biocontrol agents singly and in combinations against dry root rot (Macrophomina phaseolina) of mungbean. J. Myco. Pl. Pathol., 40(1): 141-144.

Dhingani, J. C., and Kelaiya, D. S. 2015. Management of root rot disease [Macrophomina phaseolina (Tassi) Goid.] of chick pea (Cicer arietinum L.) using antagonists in vitro. Trends in Biosciences, 8(14): 3660-3665.

Gojiya, S. K., Akbari, L. F., and Chudasama, M. K. 2016. Evaluation of biocontrol agents against Macrophomina phaseolina in vitro. Advances in Life Sciences. 5(7): 2718-2720.

Gupta, S. C., and Kolte, S. J. 1982. Cultural characteristics of leaf and root isolates of M. phaseolina (Tassi) Goid from groundnut. Indian J. Microbiol. 21(4): 345-346.

Indra, N., and Tribhuvanmala, G. 2002. Antagonism of Trichoderma spp. Again Macrophomina phaseolina causing root rot of black gram. Pl. Dis. Res. 17(1): 142-144.

Kumar, V., Kumar, A., Verma, V. C., Gond, S. K., and Kharwar, R. N. 2007. Induction of defense enzymes in Pseudomonas fluorescens treated chickpea roots against Macrophomina phaseolina. Indian Phytopath. 60(3): 289-295.

Kumar, P., Gaur, V. K., and Rani, R. 2015. Evaluation of antagonists against Macrophomina phaseolina causing root rot of groundnut. African. $J$. Micro. Res. 9(3): 155-160.

Lokesha, N. M., and Benagi, V. I. 2007. Biological management of pigeonpea dry root rot caused by Macrophomina phaseolina. Karnataka J. Agric. Sci. 20(1): 54-56.

Malathi, P., and Sabitha, D. 2004. Effect of seed priming with Trichoderma on seed-borne infection of Macrophomina phaseolina and seed quality in groundnut. Annals Pl. Prot. Sci. 12(1): 87-91.

Mallaiah, B., and Krishna Rao, V. 2016. Integrated management of dry root rot of greengram [Vigna radiata (L.) Wilczek] incited by Macrophomina phaseolina (Tassi) Goid. Int. J. Trop. Agri. 34(3): 607-614.

Manjunatha, S. V., Naik, M. K., Khan, M. F. R., and Goswami, R. S. 2013. Evaluation of bio-control agents for management of dry root rot of chickpea caused by Macrophomina phaseolina. Crop Prot. 45: 147-150.

Mathur, S. B., and Cunfer, B. M. 1993. Seed borne diseases and seed health testing of wheat. Danish government institute and pathology for developing countries. Copenhagen, pp.168.

Mayee, C. D. 1995. Current status and future approaches for management of groundnut diseases in India. Indian Phytopath. 48: 389-401.

Meena, B., and Pandey, R. N. 2015. In vitro Evaluation of biological control agents against Macrophomina phaseolina and Rhizoctonia Solani. Trends in Biosciences. 8(3): 669-671.

Morton, D. J., and Stroube, W. H. 1955. Antagonistic and stimulating effects of soil microorganism of Sclerotium. Phytopath. 45: 417-420.

Rajeswari, B., Rao, K. C., and Kumar, P. C. 1998. Antagonism of Trichoderma and Gliocladium spp. against Macrophomina phaseolina the incitant of dry root rot of mungbean. Indian $J$. Plant Prot. 26(1): 9-11.

Rani, S. U., Udayakumar, R. and Christopher, D. J. 2009. Bio-efficacy of plant extracts and bio-control agents against by Macrophomina phaseolina. Ann. Pl. Prot. Sc., (1), 389-393.

Sreedevi, B., Charitha Devi, M., and Saigopal, 
D. V. R. 2015. Isolation and screening of effective Trichoderma spp. against the root rot pathogen Macrophomina phaseolina. J. Agric. Techno. 7(3): 623-635.

Suriachandraselvan, M., Salalrajan, F., Aiyanathan, K. E. A., and Seetharaman, K. 2004. Inhibition of sunflower charcoal rot pathogen, $M$. phaseolina by fungal antagonists. $J$.
Mycol. pl. Pathol., 34(2): 364-365.

Vincent J M. Distortion of fungal hyphae in the presence of certain inhibitors. Nature. 1947; 159:850-850.

Wisniewska, H., and Chelkowski, J. 1999. Influence of exogenic salicylic acid on Fusarium seedling blight reduction in barley. Acta Physiologiae Plantarum. 21: 63-66.

\section{How to cite this article:}

Badana Manoj Kumar and Kelaiya, D. S. 2021. In-vitro Efficacy of different Bioagents against Dry Root Rot Disease of Groundnut. Int.J.Curr.Microbiol.App.Sci. 10(06): 451-457. doi: https://doi.org/10.20546/ijcmas.2021.1006.048 